Марина Ј. Шафер

Универзитет у Новом Саду

Филозофски факултет

Студент докторских студија

marina.safer@ff.uns.ac.rs doi: 10.19090/zjik.2020.11-26

UDK 811.163.41’367

оригинални научни рад

\title{
ГОВОРНИ ЧИН ОБЕһАЊА У АПОДОЗИ КОНДИЦИОНАЛНИХ РЕЧЕНИЦА
}

САЖЕТАК: У раду се испитују кондиционалне реченице чија аподоза има вредност говорног чина обећања. Посматра се и комуникативна функција протазе - у неким примерима (1) то је индиректни директив, молба/ предлог/ препорука и сл., и такве конструкције одликује погађање између адресата и адресанта, док се у другим примерима (2) протазом само описује каква ситуација, повољна за остварење обећања (а тиме и за саговорника), односно проблемска ситуација коју ће говорник решити. Даје се осврт и на синтаксичко-семантичке карактеристике овакве кондиционалне реченице. За корпус су одабране домаће телевизијске серије различитих жанрова (хумористички, драмски и криминалистички), а потом и бајке Гроздане Олујић и Десанке Максимовић. Протазни предикат у највећем броју примера оформљен је презентом глагола перфективног вида, док је аподозни предикат најчешће у облику футура првог. Иако протаза препонована аподози одсликава логички условно-последични след, у ексцерпираним примерима прилично је фреквентан и обрнут редослед - аподоза заузима прву позицију.

Кључне речи: кондиционална реченица, аподоза, протаза, обећање, комисив

\section{1. УВОДНА РАЗМАТРАЬА}

\section{1. Предмет и ичиљ истраживања}

Предмет овог рада јесте говорни чин обећања, исказан аподозом кондиционалних реченица. Испитује се и комуникативна вредност протазног дела - у неким случајевима (група 1) реч је о индиректном директиву: молби/ предлогу/ препоруци и сл. (нпр. Платићу ти сваки дан по две банке, ако га будеш увек доводио. $\rightarrow$ Увек га доводи.), и такве примере одликује погађање између говорника и саговорника, док се у другим примерима (група 2) само износи ситуација погодна за остварење обећања (нпр. Донећу ти главииу купуса, ако ме нога прође.), односно проблемска ситуација коју ће говорник решити (нпр. Уколико Вам се супруг у међувремену не јави, ми ћемо покренути истрагу и наћи ћемо га, немојте да бринете.). Анализираће 
се синтаксичке, семантичке и прагматичке карактеристике аподозе и протазе: употреба везника, глаголски облици протазног и аподозног предиката, употреба перформативних глагола (обећавам, кунем се), експлицирање личне заменице за прво лице $(j a / \mathrm{su})$ и сл. Сви примери класификовани су у две групе (1 и 2), према већ наведеним семантичкопрагматичким карактеристикама протазног дела условне реченице, док се примери друге групе даље деле у два семантичка типа ( $A$ и $D)$.

Циљ овога рада јесте утврђивање карактеристика кондиционалне реченице чија аподоза има вредност обећања, као и испитивање међусобне условљености и садејства синтаксе, семантике и прагматике у оваквим конструкцијама. Наиме, како семантичко-прагматичка структура говорног чина обећања (а посебно погађања) преферира употребу кондиционалне конструкције, тако се и синтаксичко-семантичке карактеристике кондиционалне реченице прилагођавају комуникативној вредности коју исказују (нпр. аподоза у препозицији).

\section{2. Теоријско-методолочки оквир}

\subsection{1. Говорни чин обећања (и погађања)}

Обећања се дефинишу као искази који „указују на намеру говорног лица да саопшти саговорнику да ће у будућности испунити његова очекивања или да ће извршити нешто у његову корист", и сврставају се у групу комисивних говорних чинова (Поповић 2005: 1040). ${ }^{1}$ Исто наводи и Павица Мразовић, а будући да ова ауторка примењује друкчији критеријум класификације говорних чинова, обећање сврстава у чинове који захтевају само акцију говорника (2009: 687). ${ }^{2}$ Важно је нагласити да је код обећања говорни иницијатор тај који се обавезује да ће извршити одређену радњу „Ja ne mogu da obećam da sam nešto uradio, kao što ne mogu da obećam da će neko drugi učiniti nešto (mada mogu da obećam da ću svakako gledati da on to učini)" (Serl 1991: 114-115). Серл наводи и остале услове који морају бити испуњени за успешно исказивање обећања, између осталог: слушалац би волео да говорник учини радњу више него да је не учини, и говорник верује

\footnotetext{
1 "Commissives are those kind of speech acts that speakers use to commit themselves to some future actions. They express what the speaker intends. They are promises, threats, refusals, pledges..." (Yule 1996: 54).

2 Детаљније о подели говорних чинова в. у Mrazović, Vukadinović 2009: 673-724.
} 
да би слушалац више волео да говорник учини радњу него да је не учини; ни говорнику ни слушаоцу није очигледно да ће говорник у нормалном току догађаја учинити дату радњу; говорникова интенција је да преузме одговорност да ће извршити радњу итд (1991: 110-123).

С друге стране, П. Мразовић као засебан чин издваја и погађање, које описује у групи чинова који захтевају акцију и говорника и саговорника, истичући да оно увек захтева употребу сложене реченице.3 Изричући говорни чин погађања ,govornik apeluje na spremnost sagovornika da ovaj udovolji njegovom zahtevu nudeći svoje protivusluge" (2009: 709). Ова ауторка увиђа да је код погађања акција говорника условљена противакцијом саговорника - „sagovornik je na taj način dvostruko motivisan: samim zahtevom govornika i obavezom koju govornik uzima na sebe" (2009: 709). Будући да код погађања увек постоји погодбени однос између говорника и саговорника, овај чин често се исказује управо погодбеним реченицама, које одговарају примерима групе 1 овог рада (нпр. Поклонићу ти девет бродова, ако обећаш да ником нећеш нанети зла.). За разлику од П. Мразовић, љ. Поповић говорне чинове посматра само на нивоу просте реченице. Будући да ће се у овом раду применити такав приступ, сви примери са карактеристикама погађања заправо садрже елементе два говорна чина: 1. обећање, у аподози, односно у надређеној клаузи зависносложене реченице, које је стога и примарни говорни чин зависносложене реченице, и 2. индиректни директив (предлог/ молбу/ препоруку и сл.) у протази, односно у зависној, кондиционалној клаузи зависносложене реченице. Поред оваквих примера, као што је већ наведено, испитиваће се и они чијом се протазом само износи некаква ситуација која условљава испуњење обећања, а чије остварење не зависи од саговорника, те она нема вредност индиректног директива.

\subsection{2. Кондиционална реченица}

Према познатој подели кондиционалних реченица коју предлаже Милка Ивић, а која полази од претпоставке да је ,за условљавање једне ситуације другом нужан одређени увид онога ко говори у ту другу ситуацију" (1983: 152) могу се издвојити две групе условних реченица: иреалне (говорник зна у каквој је релацији са стварношћу радња протазног

\footnotetext{
${ }^{3}$ У ову групу, поред погађања, смешта и понуду, уцену и претњу (2009: 708-711).
} 
предиката) и (евентуално)реалне (говорник не зна у каквој је релацији са стварношћу радња протазног предиката) (1983). У реалним клаузама исказује се реалан и остварљив услов (Пипер, Клајн 2013: 518). Када се наведено узме у обзир, закључује се да аподоза може имати вредност обећања само у условним реченицама реалног типа, будући да говорник нема увид у каквој је релацији са стварношћу протазна ситуација која је реална и остварљива. Везници који уводе овај тип условних клауза јесу: ако, уколико и партикула $л и$ (од којих последњи није уочен ни у једном примеру), а у корпусу се појављује и један пример сложеног (полилексичког) везника - под условом $\partial a^{4}$

\subsection{3. Експлищитни перформативни глаголи и интензификатори обећања}

„Перформативност је специфична особина појединих глагола који се у облику 1. лица једнине презента одликују еквиакционалношћу еквивалентни су чину, а не саопштењу о њему“ (Поповић 2005: 984). ${ }^{5}$ При исказивању обећања могу се јавити експлицитни перформативни глаголи: обећати и клети се (Поповић 2005: 1042; Mrazović, Vukadinović 2009: 688) (пример из корпуса: Ако преживим, све ћу да исправим, кунем ти се.). Они се наводе у аподозном делу, са допуном (мада ниједан такав случај није уочен у испитиваном корпусу), или се појављују „самостално, без пропозиције - уколико је садржај облигације изложен у претходном или наредном исказу“ (Поповић 2005: 1042). Њима се појачава степен обавезивања, а са сличном улогом јавља се и императив глагола веровати веруј ми. Врло често у аподози је експлицирана лична заменица за прво лице $(\mathrm{ja} / \mathrm{Mu})$, којом се наглашава да је управо говорни иницијатор тај који се лично на нешто обавезује, па се и њоме интензификује обећање.

\footnotetext{
4 Подробно испитујући реалне условне реченице, Милош Ковачевић даје потпун списак везника, који укључује и сложене везнике: под условом да, уз услов да, у случају да, за случај да, под/ с претпоставком да и уз претпоставку да (2013: 10). Детаљан преглед погодбених реченица учињен је и у Синтакси сложене реченице, у оквиру поглавља које се бави типологијом условљених (каузално-импликативних) односа (Војводић 2018: 458-467).

5 Душанка Звекић-Душановић запажа исти смер размишљања Џ. Л. Остина (1994: 85-87) и А. Белића (1941: 390-411) у вези са настанком експлицитних перформатива - „ови се аутори слажу у томе да су у питању структуре које су се, историјски гледано, касније развиле у језику, а узрок овоме налазе у потреби за прецизнијим, јаснијим, одређенијим изражавањем“ (2011: 20).
} 


\section{3. Корпус истраживања}

Говорни чин обећања чест је у разговорном функционалном стилу, па је део примера ексцерпиран из новијих домаћих телевизијских серија: Истине и лажи (ИиЛ), Убице мога оца (УМО) и Тајкун (Т). ${ }^{6}$ Иако у оваквим примерима формирање кондиционалних конструкција зависи и од самог аутора текста, те заправо није реч о спонтаном говору, језик наведених ТВ серија свакако одсликава дух савременог српског језика. Узети су у обзир различити жанрови како би се обухватили разноврсни ванјезички контексти: у хумористичкој драмској серији (ИиЛ) обрађују се теме из свакодневног живота, док су у криминалистичком жанру $(У M O, T)$ чести дијалози који се одвијају у полицијској станици, те су релативно фреквенте кондиционалне конструкције са обећањем у аподози, посебно оне са елементима погађања (нпр. између полицајаца и приведених: Уколико будете сарађивали, можете знатно да олакшате свој положај $(T, 1.1))$.

Други део примера ексцерпиран је из бајки Гроздане Олујић и Десанке Максимовић, будући да су оне често засићене комисивима (пред јунаке се постављају разни задаци, чије извршење бива награђивано или кажњавано).

Ексцерпирано је укупно 38 примера, 23 примера у бајкама, а 15 примера у ТВ серијама. Већи и разноврснији корпус свакако би дао и поузданије статистичке податке, али су, због ограничености дужине рада, одабрани примери обећања из два наведена жанра.

\section{2. АНАЛИЗА КОРПУСА}

Сви примери биће приказани у два поглавља (2.1. и 2.2.), издвојена на основу семантичко-прагматичких особина протазног дела. Прва група обележена је формулом $1 . \mathbf{i D}_{\mathbf{p}}+\mathbf{O}_{\mathbf{a}}$, а друга формулом $2 . \mathbf{S}_{\mathbf{p}}+\mathbf{O}_{\mathbf{a}}{ }^{7}$

\footnotetext{
${ }^{6}$ Примери су ексцерпирани из три сезоне серије Убице мога оцฺа, три сезоне серије Истине и лажи, и из прве сезоне серије Тајкун, а серије су биле емитоване на телевизији Прва и РТС1.

7 У наведеним формулама $i D$ представља индиректни директив, $S$ ситуацију/ стање, $O$ обећање, док $a$ означава аподозу, а $p$ протазу.
} 


\section{1. Груnа 1: $\boldsymbol{i} \boldsymbol{D}_{p}+\boldsymbol{O}_{a}$}

Прва група подразумева комбинацију индиректног директива (предлог/ молба/ преклињање/ савет/ препорука/ изазов и сл.) у протази и обећања у аподози. Аподозом се говорник обавезује да ће учинити нешто у корист саговорника, а с друге стране, и саговорник мора да учини нешто у корист говорника (што је наведено у протази). Стога све примере ове групе одликује погађање између адресанта и адресата. За овакву конструкцију говорник се опредељује када процени да није довољно изнети само директив - потребно је саговорника мотивисати позитивном последицом, 'наградом', обећањем, које ће уследити по испуњењу говорникове жеље, директива. ${ }^{8}$ Будући да говорник подстиче саговорника позитивном последицом (наступа 'пријатељски'), протазни директиви ретко ће имати вредност наредбе/ забране - говорник најчешће само предлаже, моли, препоручује, преклиње и сл., користи директиве нижег или врло слабог интензитета. У свим оваквим примерима говорно лице или не жели да се представља као неко ко је у позицији да наређује, или и није у позицији да може принудити саговорника на жељено понашање. ${ }^{9}$

Иако се у кондиционалним реченицама углавном прво износи протаза а затим аподоза, будући да такав редослед одсликава природни условно-последични след, у овој групи примера обрнут редослед подједнако је чест. Постављањем аподозе у иницијални положај обећање се ставља у

\footnotetext{
${ }^{8}$ Поједини аутори увиђају да се у оваквим примерима обећање приближава чину директива - Антонио Салгуеиро сматра да „главни циљ упућивања претње и давања обећања није обавезивање (говорник се обавезује да ће учинити нешто), већ директива (да натера слушаоца да нешто учини), али дефинише претњу и обећање као комбинацију комисивних и директивних чинова, коју назива комисивнодирективни чинови“ (Nikolić-Novaković 2017: 47; Salgueiro 2010: 213-228). Наведене ставове поткрепљује искључиво кондиционалним структурама. Слично наводи и љ. Поповић за примере у којима обећања нису искрена - „говорно лице полази од интенције да уверавањем саговорника у истинитост изреченог постигне нешто у своју корист, тј. да подстиче саговорника на чин и нема намеру да поступи у складу са изреченим“, закључивши да је у таквим примерима „илокутивни чин лажног обећања изједначен са директивом (нпр. Купићу ти играчку. $\rightarrow$ Знам да нећу али желим да престанеш да ми досађујеш)“(2005: 1041).

${ }^{9}$ Изузеци су примери са аподозом поштедећу mu/ поклонићу ти живот. У оваквим случајевима протаза се може разумети као наредба, будући да саговорник нема могућност избора.
} 
први план - адресату се најпре износи позитивна мотивација, 'награда', па тек онда жеља адресанта. Осим тога, у оваквим конструкцијама постоји погађање, обострана корист, однос ја теби - ти мени, те између аподозе и протазе често влада однос напоредности, истоветности, док је редослед ствари у другом плану.

a) $V_{p \text { (Prez. pf.) }}+V_{\text {a (Fut1) }}$

У највећем броју испитиваних случајева протаза је формализована презентом глагола перфективног вида, док је аподоза формализована футуром првим.

А ако то све добро урадиш, наградићу те као никада до сада (ИиЛ, $3.35) ;{ }^{10}$ Ако прође година дана а ти никога не слажеш, све ове насликане играчке претвориће се у праве. Ако прођу три године, а ти не украдеш ни парче шећера, сви ови насликани дворци и аутомобили претвориће се у праве, и све ће то бити твоје. Ако у томе богатству не заборавиш сиромахе и будеш им увек помагала, постаћеш царица у најлепшој земљи на свету (ДМ, $31){ }^{11}$ Ако до године научите све ове вештине, показаћу вам тада нове (ДМ, 588); Хајде да видимо ко ће пре стићи до месеца. Ако ти први стигнеш, признаћу ти да си бољи (ДМ, 692); Хајде да поделимо врт на пола, па да видимо у чијој ће половини цвеће брже расти. Ако твоје прво порасте, признаћу ти да си бољи (ДМ, 693); ${ }^{12}$ Дужност ми је да будем прва стража. Једино ако ме надиграш - пропустићу те (ГО, СР, 55); Сиромах сам пуки, ничег немам, али ћу те увек од зла бранити, ако ми спасеш сина (ДМ, 576); Поштедећу ти живот ако ме посаветујеш! - свечано обећа галебица, али ни риба није знала лека невољи (ГО, НР, 45); Поклонићу ти живот, а нећу дирати ни друге твоје рођаке ако одеш до старице и упиташ је шта да радим! - рече галебица и пусти рибу у море (ГО, НР, 45); Вратићу га ако нађеш воду, али ту је још нико није нашао! - јаје се подругљиво насмеја... (ГО, НР,

\footnotetext{
10 У свим примерима ексцерпираним из домаћих серија први број означава број сезоне, а други број епизоде у тој сезони. Аподозни предикати обележени су подвлачењем, док су косим масним словима обележене остале карактеристике описане у тексту који прати примере.

${ }^{11}$ Набројена обећања исказује Божић Бата.

12 У ова два наведена примера протаза има вредност изазова.
} 
55); Поклонићу ти девет бродова, ако обећаш да ником нећеш нанети зла... $(\Gamma \mathrm{O}, \mathrm{HP}, 62){ }^{13}$

$$
\text { a1) } V_{p(\text { Fut2) }}+V_{\text {a (Fut1) }}
$$

Протазни предикат може бити формализован и футуром другим, мада је његова употреба у протази ређа од употребе презента. Он је, по правилу, чест у копулативним предикатима (нпр. ако будеш добар), као и у конструкцијама са глаголима имперфективног вида (што је случај у наведеним примерима).

Сељак поче да размишља, а отац варошке деце додаде: - Платићу ти сваки дан по две банке, ако га будеш увек доводио (ДМ, 606); Ако у томе богатству не заборавиш сиромахе и будеш им увек помагала, постаћеш царица у најлепшој земљи на свету (ДМ, 31).

$$
\text { a2) } V_{p \text { (MOD) }}+V_{\text {a (Fut1) }}
$$

У два примера уочена је и употреба модалног глагола хтети у протазном предикату.

Нисам их видео, али ако хоћеш, тета Лијо Репата, да ми почистиш двориште, поћи ћу радо с тобом да их тражимо (ДМ, 634); Нисам их видео, али ћу поћи с тобом да их тражимо, само ако хоћеш уместо мене да истучеш добро мог најмлађег сина, јер ме никако не слуша. Мени су се руке већ умориле тукући га (ДМ, 634).

б) $V_{\text {p (Prez. pf.) }}+V_{\text {a (Prez. MOD) }}$

Уочени су и примери са модалним глаголом моћи у аподози, у првом и у другом лицу презента. Иако овај модални глагол није типичан за чин обећања (више упућује на предлог), цела конструкција која је погодбеног значења јасно указује на то да се аподозом говорно лице обавезује да ће извршити по саговорника пожељну радњу.

\footnotetext{
13 У наведеном примеру протазом говорник захтева од саговорника вербално обавезивање - да му обећа да ће у будућности поступати на одређени начин.
} 
У једном примеру испитиваног корпуса јавља се сложени везник под условом да. Милош Ковачевић уочава да поред тога што се овим везником у први план ставља „да услов у протази прати реализацију садржаја у аподози“, он углавном сигнализира и ,да је испуњење услова у протази пожељно са становишта адресанта“ (2013: 28), те не изненађује његова појава у случајевима када аподоза има вредност обећања а читава конструкција вредност погађања - тада је протазна радња свакако пожељна са становишта адресанта. Осим тога, овај сложени везник углавном се јавља у специјалним функционалним стиловима (научни и административноправни), а у овом случају реч је о ‘формалној' погодби, у полицијској станици. ${ }^{14}$ И у примеру са везником уколико такође је реч о 'формалној' погодби, мада је употреба овог везника свакако шира. ${ }^{15}$

Ми можемо да средимо и да добијеш условну, наравно, под условом $\boldsymbol{\partial} \boldsymbol{a}$ нам признаш све, да се покајеш, да унесемо у записник да си дао кључне информације за раскринкавање тих криминалаца (ИиЛ, 3.61).

б1) $\mathbf{V}_{\mathbf{p} \text { (Fut2) }}+\mathbf{V}_{\mathbf{a} \text { (Prez. MOD) }}$

Иако је у овом примеру модални глагол у другом лицу, односно површински субјекат идентичан је у протази и аподози (те се наизглед нарушава идеја погађања која подразумева два субјекта - адресанта и адресата - у двема клаузама, протазној и аподозној), дискурсно је јасно да се у аподози имплицира други субјекат - адресант (ви можете да олакшате свој положај $\rightarrow$ ми ћемо вам олакшати положај).

Уколико будете сарађивали, можжете знатно да олакшате свој положај (T, 1.1).

\footnotetext{
14 За разлику од везника под условом да, сложени везници у случају да/ за случај да сигнализирају да је реч о „неком непријатном, неочекиваном, непредвидљивом догађају као услову за реализацију ситуације означене надређеном клаузом, који се настоји представити као мало вјероватан“ (Ковачевић 2013: 28), те се не јавља у кондиционалним реченицама са значењем погађања. И његова употреба чешћа је у специјалним функционалним стиловима.

${ }^{15}$ У литератури се наводи да је везник уколико „,osobitost administrativnog stila“ (Silić, Pranjković 2005: 348), односно да је „обичнији у научном, административном и публицистичком стилу, мада се среће и у другим функционалним стиловима“ (Пипер, Клајн 2013: 518). Исто уочава и М. Ковачевић, испитујући везнике реалне условне реченице на корпусу који укључује више од 500 реченица (2013: 18).
} 


\section{2. Група 2: $\boldsymbol{S}_{\boldsymbol{p}}+\boldsymbol{O}_{\boldsymbol{a}}$}

Друга издвојена група примера подразумева опис какве ситуације у протази и позитивну последицу по саговорника, обећање, у аподози. На протазну ситуацију саговорник не може да утиче: она зависи или од неког трећег лица, или од природног развоја разних околности, или је за њу заслужан сам саговорник, али ту више ништа не може да се промени (ситуација је резултат неке прошле радње). Оваква семантичка вредност протазе утицаће и на отварање нових могућности формализације протазног предиката (пре свега, на употребу перфекта и презента глагола имперфективног вида у протазном предикату).

Према садржају протазне ситуације, могу се издвојити два доминантна семантичка типа: тип $A$, чија протаза описује неку проблемску ситуацију, негативну по судбину адресата $\left(\mathrm{S}_{\mathrm{p}}^{(-)}+\mathrm{O}_{\mathrm{a}}\right)$, и тип 5 , чија протаза описује неку повољну ситуацију, позитивну по судбину адресата $\left(\mathrm{S}_{\mathrm{p}}^{(+)}+\mathrm{O}_{\mathrm{a}}\right)$.

\subsection{1. Тип $\mathrm{A}: \mathbf{S}_{\mathbf{p}}^{(-)}+\mathbf{O}_{\mathbf{a}}$}

У првом семантичком типу протазни садржај представља неку проблемску ситуацију, негативну по саговорника, а говорник аподозом обећава да ће решити или бар покушати да исправи наведену непогодност. То може бити каква непријатност изазвана одговорношћу трећег лица (нпр. нестанак неке особе), а говорник се обавезује да ће у тој ситуацији саговорнику помоћи (нпр. проналаском те особе). У појединим примерима говорник се чак обавезује да ће нашкодити трећем лицу како би исправио неправду коју је треће лице нанело адресату.

У свим ексцерпираним примерима који су увршћени у ову семантичку групу у аподози је експлицирана заменица за прво лице $(\mathrm{ja} / \mathrm{Mu})$, чиме је наглашено обавезивање адресанта на будући чин, појачана је лична говорникова одговорност за истинитост обећања. Улогу интензификације обећања има и експлицитни перформативни глагол - обећавати, као и императив глагола веровати са допунском клаузом (веруј ми да...), којим говорник убеђује саговорника да говори истину. У свим случајевима протаза је препонована аподози. 
a) $V_{p \text { (Prez. pf.) }}+V_{\text {a (Fut1) }}$

Али, уколико Вам се супруг у међувремену не јави, ми ћемо покренути истрагу и наћи ћемо га, немојте да бринете (ИиЛ, 3.29); Ако ме стисну, $\boldsymbol{j} \boldsymbol{a}$ ћу рећи да те нисам проверавао (УМО, 1.8); Али немој да бринеш, ако направи неке глупости, $\boldsymbol{j} \boldsymbol{a}$ ћу да га_доведем у ред одмах (ИиЛ, 3.28).

$$
\text { a1) } \mathbf{V}_{\mathbf{p} \text { (Pf) })}+\mathbf{V}_{\mathbf{a} \text { (Fut1) }}
$$

Оваква синтаксичка комбинација омогућена је захваљујући томе што у тренутку говора говорнику још увек није познато да ли је поступак који је направио у прошлости грешка или није. ${ }^{16}$

Ја, ако сам нешто погрешио, ja ћу то да исправим (ИиЛ, 3.40); Лука, уколико сам те неправедно оптужио, што ћемо тек подробно да истражимо, $j \boldsymbol{a}$ ћу да ти се извиним (ИиЛ, 3.46).

б) $\mathbf{V}_{\mathbf{p} \text { (Prez. pf.) }}+\mathbf{V}_{\mathbf{a} \text { (Imper. + kompl. klauza) }}$

У овом примеру обећање је интензификовано на више начина: употребом императива глагола веровати уз датив личне заменице за прво лице (ми) и са допунском клаузом, употребом експлицитног перформативног глагола обећати, и експлицирањем личне заменице за прво лице $(j a)$.

И ако га не врати до сутра, веруј ми да ће имати посла са свима нама. Ево ја ти то обећавам (ИиЛ, 3.30).

2.2.2. Тип Б: $\mathrm{S}_{\mathrm{p}}^{(+)}+\mathrm{O}_{\mathrm{a}}$

$\mathrm{У}$ други семантички тип, тип $\delta$, увршћени су примери са ситуацијом позитивном по саговорника у протази и обећањем у аподози. Таква ситуација може бити у правом смислу речи позитивно обележена (нпр. престанак бола y нози/ преживљавање и сл.), или пак било каква околност у којој ће се наћи говорни иницијатор, а која ће бити повољна како би он учинио нешто од чега би саговорник имао користи (нпр. ако нешто сазна/ чује он ће га

\footnotetext{
${ }^{16}$ Када се услов реалне условне реченице односи на сферу прошлости, најчешће је присутна семантичка компонента, „да говорно лице не зна да ли је реализована прошла условна радња““ (Ковачевић 2013: 12; Ivić 1983: 150).
} 
обавестити и сл.). И у примерима овог типа уочена је употреба перформативних глагола обећати и клети се.

a) $V_{\text {p (Prez. pf.) }}+V_{\text {a (Fut1) }}$

Донећу ти главицу купуса, ако ме нога прође (ДМ, 576); А довече ћеш имати проје, ако ми газда Пера дадне (ДМ, 664); Oбећај ми да ћеш му се вратити. -Добро, ако ме позове, вратићу се (ИиЛ, 2.48); Ако чујем кадгод да мали сиротан не проси, испричаћу вам како се то догодило (ДМ, 601); Ако наиђем на врапчиће што се сваки дан играју пред твојом кућом, peћи ћу им да их много волиш и послаћу их сутра теби на доручак (ДМ, 542); Ако преживим, све ћу да исправим, кунем ти се (УМО); У сваком случају, ако нешто сазнам због чега би требало да бринеш, $\boldsymbol{j} \boldsymbol{a}$ ћу ти то рећи. - Хвала ти пуно (ИиЛ, 2.44); Треба га казнити за његова безакоња. $\boldsymbol{J a}$ ћу подићи чету јелена у потеру, и судићемо му, ако га нађемо (ДМ, 688); Ја одмах одох са својим ројем да га гоним. Ако га нађемо, сасућемо му све своје жаоке у крв, па му неће више пасти на ум да дира мирне путнике и становнике наше шуме (ДМ, 688).

a1) $\mathbf{V}_{\mathbf{p}(\text { Fut2) }}+\mathbf{V}_{\mathbf{a} \text { (Fut1) }}$

Добро, морам да идем. $\boldsymbol{J a}$ ћу вам јавити ако буде нешто ново (ИиЛ, 3.44); Не плачи, донећу ти са доњег света опет штогод лепо, само ако будем још једном тамо ишао (ДМ, 677).

a2) $\mathbf{V}_{\mathrm{p} \text { (Prez, impf.) }}+\mathbf{V}_{\mathrm{a} \text { (Fut1) }}$

Хајд’ овако, помоћи ћу ти, ако је план добар (ИиЛ, 3.2).

a3) $\mathbf{V}_{\text {p (MOD) }}+\mathbf{V}_{\text {a (Fut1) }}$

Протазни предикат има модално значење - садржи лексему шанса, којом се означава могућност.

Ако постоји иоле шанса да га пребацимо у Србију, решићемо то. Обећавам (T, 1.6). 
a4) $V_{p \text { (Perf.) }}+V_{\text {a (Fut1) }}$

Ако сте све задатке свршиле, ићи ћемо данас после подне заједно да донесемо бадњак, - рекао им је благо тата јер је веровао да су збиља све задатке научиле (ДМ, 616).

\section{3. ЗАКЉУЧНА РАЗМАТРАњА}

Анализирајући кондиционалне реченице реалног типа чија аподоза има вредност говорног чина обећања, ексцерпираних из бајки и домаћих серија, могу се издвојити одређене правилности формирања оваквих конструкција, на прагматичком, семантичком и синтаксичком нивоу.

Уколико аподоза, као главна клауза, па тако и носилац комуникативне вредности кондиционалне реченице, има функцију обећања, у једној групи примера (1) протаза има вредност говорног чина индиректног директива, углавном слабијег интензитета - молбе/ предлога/ препоруке и сл. (iD $D_{p} O_{a}$ : Платићу ти сваки дан по две банке, ако га будеш увек доводио. $\rightarrow$ Увек га доводи.), док у другој групи случајева (2) протаза само описује какву ситуацију: (А) неповољну по слушаоца $\left(\mathrm{S}_{\mathrm{p}}{ }^{(-)}+\mathrm{O}_{\mathrm{a}}\right.$ : И ако га не врати до сутра, веруј ми да ће имати посла са свима нама), а аподозом се обећава исправљање те неправде, односно ситуацију (Б) повољну по слушаоца, будући да омогућава испуњење обећања $\left(\mathrm{S}_{\mathrm{p}}^{(+)}+\mathrm{O}_{\mathrm{a}}\right.$ : $A$ довече ћеш имати проје, ако ми газда Пера дадне.). У примерима групе 1 успоставља се однос погађаға између адресанта и адресата, а најчешћа синтаксичка комбинација глаголских облика предиката јесте презент глагола перфективног вида у протази, и футур први у аподози. Протазни предикат може бити формализован и футуром другим, што је ређи случај у поређењу са презентом, а у неколико примера аподозни предикат лексикализован је модалним глаголом моћи (мада се такве аподозе приближавају вредности предлога). У примерима групе 2 отварају се и друкчије синтаксичке могућности - протазни предикат може бити формализован и обликом перфекта, односно презентом глагола имперфективног вида, мада је и код њих најчешћа синтаксичка комбинација $\mathrm{V}_{\mathrm{p} \text { (Prez. pf.) }}+\mathrm{V}_{\mathrm{a} \text { (Fut1) }}$.

У неколико примера уочени су и перформативни глаголи обећати и клети се, а у једном примеру обавезивање је интензификовано императивом глагола веровати. У великом броју случајева у аподози је експлицирана лична заменица за прво лице $(j a / \mathrm{Mu})$, која такође утиче на интензификацију обећања. 
Што се тиче везника, најбројнији је свакако везник ако, али је у два случаја регистрован и везник уколико, а у једном примеру протаза је уведена сложеним везником под условом да. Учесталост појављивања везника могла би се поузданије утврдити на већем (и разноврснијем) корпусу.

Иако је за кондиционалне реченице уобичајено да протаза претходи аподози (што и одсликава условно-последични след ствари), у повећем броју примера (37\%) даје се обрнут редослед - аподоза заузима прво место, чиме се обећање ставља у први план. То је посебно видљиво у првој групи, у примерима с погађаъем: говорник саговорнику најпре износи мотив (награду, позитивну последицу, обећање), па тек онда своје жеље и захтеве. Међутим, на редослед протазе и аподозе утичу и други фактори, нпр. то да ли је услов очекиван или не (уколико је мала вероватноћа да протазна ситуација ступи на снагу, она се често даје тек узгредно, после аподозе), тако да би се и овакви закључци морали проверити на обимнијем корпусу.

\section{ИЗВОРИ}

ГО, НР: Олујић, Гроздана. 2009. Небеска река и друге бајке. Антологија српске књижевности. www.ask.rs

ГО, СР: Олујић, Гроздана. 2009. Седефна ружа и друге бајке. Антологија српске књижевности. www.ask.rs

ДМ: Максимовић, Десанка. 2012. Целокупна дела, Том 7. Проза за деиу. Београд: Задужбина Десанке Максимовић; Београд: Завод за уџбенике; Београд: Службени гласник.

ИиЛ: Истине и лажи. 2018, 2019. www.dailymotion.com

T: Тајкун. 2020. www.gledajonline.net

УМО: Убище мога ой. 2016, 2017, 2018. www.gledajonline.net

\section{ЛИТЕРАТУРА}

Белић, Александар. 1941. O језичкој природи и језичком развитку: лингвистичка испитивања. Београд: Српска краљевска академија.

Војводић, Дојчил. 2018. „Погодбена условљеност“. Синтакса сложене речениие у савременом српском језику (ур. П. Пипер). Београд: Институт за српски језик САНУ, Београдска књига; Нови Сад: Матица српска, 458-467.

Ивић, Милка. 1981. „Српскохрватски глаголски облици за исказивање појава које постоје у садашњости“. Јужнословенски филолог XXXIII: 12-24. 
Ковачевић, Милош. 2013. „Реченице с реалноусловним везницима у савременом српском језику“. Радови Филозофског факултета Пале, Филолошке науке, бр. 15, књига 1: 9-32.

Пипер, Предраг, Клајн, Иван. 2013. Нормативна граматика српског језика. Нови Сад: Матица српска.

Поповић, Људмила. 2005. „Комуникативне функције просте реченице“. Синтакса савременога српског језика (ур. М. Ивић). Београд: Институт за српски језик САНУ, Београдска књига; Нови Сад: Матица српска, 983-1057.

Танасић, Срето (2005), „Синтакса глагола“. Синтакса савременога српског језика (ур. М. Ивић). Београд: Институт за српски језика САНУ, Београдска књига; Нови Сад: Матица српска, 345-470.

$* * *$

Zvekić-Dušanović, Dušanka. 2011. Modalnost: Motivaciona modalnost u srpskom i mađarskom jeziku. Novi Sad: Filozofski fakultet, Odsek za srpski jezik i lingvistiku.

Ivić, Milka. 1983. „O srpskohrvatskim pogodbenim rečenicama“. Lingvistički ogledi. Beograd: Prosveta.

Mrazović, Pavica, Vukadinović, Zora. 2009. Gramatika srpskog jezika za strance. Sremski Karlovci - Novi Sad: Izdavačka knjižarnica Zorana Stojanovića.

Nikolić-Novaković, Lidija. 2017. Forenzička lingvistika. Primena metoda forenzičke lingvistike u kriminalističkim istragama pretnje. Banjaluka: Evropski defendologija centar za naučna, politička, ekonomska, socijalna, bezbjednosna, sociološka i kriminološka istraživanja.

Ostin, Džon L. 1994. Kako delovati rečima. Novi Sad: Matica srpska.

Serl, Džon. 1991. Govorni činovi. Ogled iz filozofije jezika. Beograd: Nolit.

Silić, Josip, Pranjković, Ivo. 2005. Gramatika hrvatskoga jezika za gimnazije $i$ visoka učilišta. Zagreb: Školska knjiga.

***

Yule, George. 1996. Pragmatics. New York: Oxford University Press.

Salgueiro, Antonio. 2010. "Promises, Threats and the Foundation of Speech Act Theory". Pragmatics: 213-228. 
Marina J. Šafer

\section{SPEECH ACT OF PROMISE IN CONDITIONAL CLAUSE APODOSIS}

\section{Summary}

The paper analyses conditional clauses with apodoses that are classified as speech acts of promise. It also observes the communicative protasis function - in some examples (1) it is an indirect directive, a plea/ suggestion/ request/ recommendation, etc. Structures like these are characterized by a bargain struck between the addressant and adressee. In other examples (2) the protasis only describes a situation that is beneficial both to the realization of the promise and to the interlocutor. It also describes a problematic situation that the speaker is going to solve. The author also points out the syntactic and semantic characteristics of such conditional sentences: the use of conjunctions, protasis and apodosis predicate structure, the arrangement of the protasis and apodosis part, etc. The corpus includes select Serbian television shows of different genres (comedy, drama, and crime), and works of children prose by Desanka Maksimović and Grozdana Olujić. In most cases, the protasis predicate is formed as present verb of perfective aspect, while the apodosis predicate is mostly in Future I form. Although the protasis that precedes the apodosis infers a logical cause-consequence flow, which makes this arrangement common in conditional clauses, in excerpted examples, the inverted arrangement is also frequent - the apodosis takes the first position, bringing the promise in focus, while the interlocutor's offer is secondary.

Keywords: conditional clause, apodosis, protasis, promise, comissive 